\title{
Antibiotic prescribing and resistance: knowledge level of medical students of clinical years of University Sultan Zainal Abidin, Malaysia
}

This article was published in the following Dove Press journal:

Therapeutics and Clinical Risk Management

12 March 2016

Number of times this article has been viewed

\section{Mainul Haque \\ Nor Iza A Rahman \\ Zainal Zulkifli \\ Salwani Ismail}

Faculty of Medicine, Universiti Sultan Zainal Abidin, Kuala Terengganu,

Terengganu, Malaysia

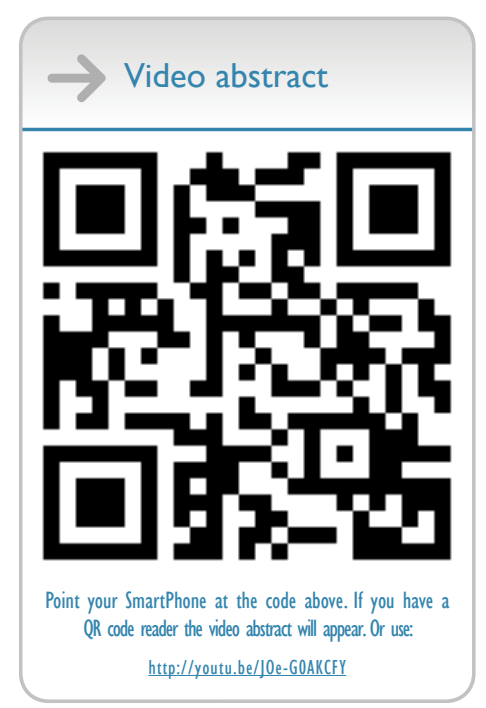

Correspondence: Mainul Haque Faculty of Medicine, Universiti Sultan Zainal Abidin, Medical Campus, Jalan Sultan Mahmud, 20400 Kuala Terengganu, Terengganu, Malaysia

Tel +60 I0 9265543

Email runurono@gmail.com
Abstract: The innovation of penicillin by Dr Alexander Fleming in 1928 and its use in clinical practice saved many lives, especially during the Second World War. Tuberculosis still carries a significant public health threat and has re-emerged over the past two decades, even in modern countries where tuberculosis was thought to be eliminated. The World Health Organization defines antimicrobial resistance as the resistance of a microorganism to an antimicrobial drug that was initially effective for treatment of infections caused by the microbe. Therefore, the findings of the current study will provide data to enable the design of a new educational program to better equip our students in confronting antimicrobial resistance. This study was a cross-sectional, questionnaire-based survey, which was undertaken in the Faculty of Medicine, Universiti Sultan Zainal Abidin, Kuala Terengganu, Malaysia. The study participants were students of the Bachelor of Medicine and Bachelor of Surgery program (MBBS) of Year III, IV, and V. A total of 142 out of $164(86 \%)$ medical students returned the questionnaire. Specifically, the year-wise breakdown of responses was 29\% (41), 39\% (55), and 32\% (45) for Year III, IV, and V, respectively. Among the study respondents, 28\% (40) were male, and the remaining 72\% (102) were female. In all, $67 \%$ of the participants felt more confident in "making an accurate diagnosis of infection/ sepsis." The majority ( $88 \%$ ) of the study participants stated that they would like more training on antibiotic selection. This research has found that there is a gap between theoretical input and clinical practice; the students are demanding more educational intervention to face the threat of antimicrobial resistance.

Keywords: antibiotic, prescribing, resistance, medical students, knowledge, Malaysia

\section{Introduction}

Selman Waksman first used the word antibiotic as a noun in 1941 to describe any small molecule made by a microbe that antagonizes the growth of other microbes. ${ }^{1} \mathrm{Dr}$ Alexander Fleming published his findings of the discovery of penicillin in the British Journal of Experimental Pathology in 1929, and by the 1940s penicillin use was commonplace in clinical practice. This saved many lives, especially during the Second World War. ${ }^{2-4}$ Penicillin was followed by the invention of a number of antibiotics from 1945 to 1955 , namely, streptomycin, chloramphenicol, and tetracycline. ${ }^{1,4}$ All of these antimicrobials were produced by microbes, actinomycetes and fungi being the unique resources. ${ }^{1,4}$ The development of antimicrobials not only conquered the management of infectious diseases but also raised the average life expectancy and quality of life for humanity. Therefore, this outstanding achievement led to the belief that "infectious diseases would be conquered shortly." Although the history of clinical uses of antimicrobials is quite recent, the antibiotic tetracycline has been identified as far back 
as 350-550 CE among the skeletons of the ancient Sudanese Nubia population. ${ }^{6,7}$ Similar findings were also reported in femoral bones found in the Dakleh Oasis, Egypt. ${ }^{8,9}$ It has led to the notion that both of these ancient communities' diets contained tetracycline. The presence of antimicrobials in foods in these prehistoric societies possibly gave protective effects from microbes. Therefore, these communities suffered either low or no infectious diseases. ${ }^{6-9}$

Tuberculosis (TB) still carries a significant public health threat and has re-emerged over the past two decades, even in modern countries where TB was thought to be eliminated. ${ }^{10-12}$ TB was declared a global emergency by the World Health Organization (WHO) in 1993, with around 8-10 million new cases annually and over 2-3 million deaths worldwide. ${ }^{13}$ The WHO defines "AR [antimicrobial resistance] as the resistance of a microorganism to an antimicrobial drug that was initially effective for treatment of infections caused by it."14 Resistance is also defined "as bacteria that are not inhibited by usually an achievable systemic concentration of an agent with the regular dosing schedule and/or fall in the minimum inhibitory concentration ranges." 15 Similarly, multiple drug resistance is defined as the acquired nonsusceptibility to three or more antimicrobial drugs or drug classes. ${ }^{16,17}$ The term multiple drug resistance initially was used to identify resistant malignant tumors, and later of Mycobacterium tuberculosis. Now it is used for any microbial infections bacterium, fungus, or parasite. ${ }^{18}$ Acquisition of resistance to one antibiotic conferring resistance to another antibiotic, to which the organism has not been exposed, is called crossresistance. ${ }^{19-22}$ In all, $80 \%-90 \%$ of the antibiotics are prescribed for ambulatory patients; the rest in hospital admitted cases. ${ }^{23}$ It is also reported that general practitioners prescribe $90 \%$ of antimicrobials. ${ }^{24}$ It has been estimated in the US by state-sponsored research that 50 of the 150 million prescriptions for antibiotics written for outpatients every year are not evidence-based. ${ }^{25}$ It has been also identified that as high as $50 \%$ of antimicrobials are used without any scientific basis, and antibiotic was prescribed that was either superfluous or debatable. ${ }^{26-28}$ Multiple studies reported that these very dangerous resistant microbes were created due to misuse of antimicrobials. ${ }^{29-31}$ The consequences are an increased riskof additional morbidity and mortality by snowballing the possibility of adverse drug reactions and promotion of AR in community pathogens. ${ }^{32}$ Researchers have pointed out that globalization ensures quick spreading of antibiotic resistance, for example, the rapid international spread of New Delhi metallo-blactamase. ${ }^{33,34}$ Therefore, there is an urgent need for an international and nationwide platform to control AR. ${ }^{35-39}$
European AR Surveillance Network, National AR Monitoring System for Enteric Bacteria (USA), The Surveillance Network (USA), AR Surveillance (Germany), Central Asian and Eastern European Surveillance on AR, and Surveillance of Antibiotic Use and Bacterial Resistance in German Intensive Care Units are the most important investigation programs currently working on AR. ${ }^{35}$

Although the Ministry of Health, Malaysia, has been issuing antibiotic use guidelines for more than two decades, compliance with these guidelines was found to be lacking. ${ }^{40}$ The same study also reported that antibiotic resistance is common in Malaysian general hospitals. ${ }^{40}$ In 1994, another study reported that ampicillin, cloxacillin, cephalosporins, gentamicin, co-trimoxazole, and tetracyclines were highly resistant in six Malaysian general hospitals. Researchers concluded that AR is a "constant threat and challenge for clinicians" in Malaysia especially in treating nosocomial infections. ${ }^{41}$ The Medical Journal of Malaysia in 2003 published three articles on the issue of AR in Malaysian communities. All three of these articles were highly concerned about AR and its impact on public health. ${ }^{42-44}$ Dr VKE Lim, a very renowned physician in Malaysia, in his recent editorial review of the subject, mentioned that a multifaceted strategy is required to improve antibiotic prescribing and control the emergence of antibiotic resistance. Education of both doctors and patients would form the cornerstone of the strategy. ${ }^{45}$ Another three studies of research published in 2004, 2011, and 2013 reported that a significant proportion of antimicrobials were prescribed inappropriately especially in upper respiratory tract infection. These studies concluded that this irrational prescribing would promote more AR. ${ }^{46-48}$ These studies accept that more educational intervention will promote rational prescribing and professional responsibility, which will ultimately enlighten health professionals with more expertise against AR. ${ }^{46-48}$ A number studies conducted in the general public of Malaysia reported that Malaysians have inadequate knowledge about antimicrobials. These findings reinforce the notion that there is an urgent need for an educational program to raise awareness and advocate a movement among patients. ${ }^{49-51}$ Another study reported that a poor knowledge level exists among the general public of Malaysia, and this promotes more frequent and incorrect use of antimicrobials. The same survey also encouraged educational intervention among ordinary citizens. ${ }^{52}$ Professor Lim again mentioned in his recent review that the global public threat of AR can only be addressed through good antibiotic stewardship programs. To overcome the global public health threat of AR, all relevant stakeholders of the health service should work in unison. ${ }^{53}$

Rational prescribing is the paramount issue in the struggle against AR. It is tough to convey new ideas to doctors 
and other health professionals because they are already entrenched in their own notions and thoughts. Therefore, it is suggested that intervention should be conducted during the early days of medical training. The WHO, in 2012, has emphasized the importance of rational prescribing in the undergraduate medical curriculum. ${ }^{54}$ There were different levels of awareness regarding prescribing, but almost every study recommended more educational interventions in the undergraduate curriculum. ${ }^{55-65}$ Different studies emphasized that teaching and learning about antimicrobials, both at the undergraduate and postgraduate medical curricula, remain the most noteworthy approach in the fight against AR. ${ }^{55,66-68}$ Antimicrobials are "considered among the essential drugs of a core curriculum in clinical pharmacology for undergraduate medical students." 69

Although there are some related studies conducted throughout the world, there were not many studies specific to Malaysia. One pilot study published in 2014 suggested extensive improvement of the curriculum and education for health care professionals to ensure the rational use of antimicrobials. ${ }^{70}$ The first batch of medical students admitted at Universiti Sultan Zainal Abidin (UniSZA) was in 2009, graduated in 2014 , to work as house officers in different hospitals for the Ministry of Health, Malaysia. ${ }^{71}$ As other universities in Malaysia, UniSZA is subscribed to the integrated curriculum for undergraduate medical education and pharmacology is taught in preclinical years of Year I and II as a lecture-based subject. ${ }^{72}$ The Faculty of Medicine, UniSZA, is scheduled to conduct a major revision in the next few years of the undergraduate medical curriculum..$^{73,74}$ Therefore, this exercise is to ensure highly professional and committed medical doctors are produced in society. ${ }^{75-78}$ Medical students are future doctors for any society, and they are the primary stakeholders in any health care system. ${ }^{60}$ Therefore, their beliefs and practices regarding antibiotic prescribing and resistance will have an impact on AR. The current study will provide suitable data to design a new educational program to equip our students in their fight against AR. UniSZA is a new medical school in Malaysia and the first two batches have already graduated and are working as house officers in different government tertiary hospitals of Malaysia. It is mandatory for the faculty of medicine to reorganize and review the curriculum according to the Malaysian Government regulation. ${ }^{73,74}$

\section{Materials and methods}

This study was a cross-sectional, questionnaire-based survey, which was undertaken in the Faculty of Medicine, UniSZA, Malaysia. The study participants were students of the MBBS program in Year III, IV, and V. As the total population size was 179, a universal sampling method was applied to select the respondents. Data were collected from May to June 2015 using a validated instrument. The principal author was much impressed with a multicenter study conducted in Europe. ${ }^{65}$ He contacted the corresponding author Professor (Dr) Ce'line Pulcini in France and obtained formal permission to use the validated instrument. The questionnaire was again pretested and validated in the local context. The questionnaire was administered to 15 medical students who did not participate in the primary study. Their responses were collected and analyzed for validity and reliability. The Cronbach alpha was calculated as 0.69 . A total of 164 (179-15 non-participants) questionnaires were given to the study respondents after a prearranged lecture class. They were asked to complete anonymously the questionnaires. Study respondents were given 15 minutes to complete the questionnaire which was handed over immediately to the principal investigator.

The questionnaire consisted of 21 questions. Initially, demographic features were recorded. The first question was a 5-point Likert scale, where responses ranged from "very unconfident" to "uncertain". It was used to assess the respondent's confidence in prescribing. Six questions were set to give an idea of the student's training in antibiotic prescribing. Out of six, five questions were arranged in the Likert scale-based questions with options of "yes", "no", and "unsure". One question was to assess the total hours of training the respondents had received during their undergraduate study. Then, the next five questions were set to evaluate the respondent's knowledge of AR. Two of these were set out so as to put a tick mark for "yes", "no", or "unsure". The other three questions were arranged in six rows, which indicated the percentage range in the following manner: row 1 was up to $1 \%$, row 2 was $>1 \%-20 \%$, row 3 for $21 \%-40 \%$, row 4 for $41 \%-60 \%$, row 5 included $61 \%-80 \%$, and the last row showed a percentage range from $81 \%$ to $100 \%$. The selfreported practices regarding the antibiotic usage of the study population were also assessed by using two questions that consisted of five rows. Each row showed the percentage range in the answer. Ranges of percentage were $1 \%-20 \%$ in the first row, $21 \%-40 \%$ in the second, $41 \%-60 \%$ in the third, $61 \%-80 \%$ in the fourth, and finally $81 \%-100 \%$ in the fifth. The respondent's perception of the factors contributing to antibiotic resistance was assessed by another question that consisted of a 4-point Likert scale, whose responses ranged from "very important" to "not important at all". The next two knowledge-based questions were about the number of new classes of antibiotics that became clinically available in 
the last 30 years as well as those that will become available in the next 30 years. The last three questions were used to assess the respondent's perceptions of AR.

There are four routes available to students to pursue a degree program in Malaysia. The Ministry of Education conducts two qualifying programs to the first degree programs: the first program allows students to matriculate at secondary school. This program is usually a 1-year program, but may extend up to 2 years if necessary. The majority of UniSZA students have completed the 1-year matriculation program. The second route is the Malaysia Certificate of Higher Education, which is a 1.5-year program. Also, a 1-year foundation training is conducted by top Malaysian universities. Finally, students can opt to complete a diploma after secondary school, and later apply for entry into a degree program. ${ }^{71}$

This research obtained UniSZA Research Ethics Committee (UHREC) ethical approval; the certificate was obtained (UniSZA. C/1/UHREC/628-1 [4], March 5, 2015) before the study was conducted. Research ethics were strictly maintained, especially regarding confidentiality. Explanation concerning the purpose of the study was given, and informed consent was obtained verbally from the participants to utilize their data for research purposes. UHREC had examined the questionnaire before the study was started. UHREC was satisfied that there were no sensitive questions. The current research was a questionnaire-based knowledge, attitude, and practice study, which was totally anonymous and voluntary. Thus, researchers thought verbal consent was sufficient. The principal investigator informed UHREC and took permission for the verbal consent procedures before data collection began. This study recovered $86 \%$ of the questionnaires as respondents were given total liberty to refuse the study. Simple descriptive statistics were used to generate frequencies and percentages using SPSS Version 20 (IBM Corporation, Armonk, NY, USA).

\section{Results}

\section{Demographic profile}

A total of 142 out of 164 (86\%) medical students returned the questionnaire. Specifically, the year-wise response was 29\% (41), 39\% (55), and 32\% (45) for Year III, IV, and V, respectively. Among the study respondents, 28\% (40) were male, and the remaining $72 \%$ (102) were female. The majority $(92 \%, 131)$ of the respondents were single, but the rest were either engaged $(5 \%, 7)$ or married $(2 \%, 3)$. Similarly, the majority of the current study population were Malay $(82 \%, 116)$ and the rest were either Indian $(10 \%, 14)$ or Chinese $(7 \%, 10)$ in ethnic origin. The study population had different religious backgrounds; 84\% (119) identified as Muslim, Hindu $(8 \%, 11)$, Buddhist $(6 \%, 8)$, and Christian $(1 \%, 2)$. In all, $78 \%(111)$ of the present study population have undergone a 1-year matriculation and the rest either a 2 -year matriculation $(1 \%, 2)$ or other $(17 \%, 24)$ (Table 1$)$.

\section{Levels of confidence in prescribing}

The participants felt more confident in "making an accurate diagnosis of infection/sepsis" $(67 \%, 95)$, "interpreting microbiological results" $(55 \%, 78)$, "choosing the correct antibiotic" $(55 \%, 78)$, "choosing the correct dose and interval of administration" $(42 \%, 52)$, "using a combination therapy if appropriate" $(44 \%, 63)$, "choosing between intravenous and oral administration" $(56 \%, 79)$, “deciding not to prescribe an antibiotic if the patient has fever, but no severity criteria, and if you are not sure about your diagnosis" $(56 \%, 79)$, "planning to streamline/stop the antibiotic treatment according to the clinical evaluation and investigations" (51\%, 72 ), and "planning the duration of the antibiotic treatment" $(49 \%, 69)$. The respondents felt unconfident in "interpreting microbiological results" $(25 \%, 36)$, "choosing the correct antibiotic" $(30 \%, 42)$, "choosing the correct dose and interval of administration" $(42 \%, 60)$, "using a combination therapy if appropriate" $(40 \%, 57)$, "deciding not to prescribe an antibiotic if the patient has fever, but no severity criteria, and

Table I Demography of study population $(n=\mid 42)$

\begin{tabular}{|c|c|c|}
\hline Variable & $\mathbf{n}$ & $\%$ \\
\hline \multicolumn{3}{|c|}{ Sociodemographic characteristics } \\
\hline \multicolumn{3}{|c|}{ Sex } \\
\hline Male & 40 & 28.2 \\
\hline Female & 102 & 71.8 \\
\hline \multicolumn{3}{|l|}{ Marital status ${ }^{\mathrm{a}}$} \\
\hline Single & $|3|$ & 92.2 \\
\hline Engaged & 7 & 4.9 \\
\hline Married & 3 & 2.1 \\
\hline \multicolumn{3}{|l|}{ Race $^{b}$} \\
\hline Malay & 116 & 81.7 \\
\hline Chinese & 10 & 7.0 \\
\hline Indian & 14 & 9.9 \\
\hline \multicolumn{3}{|l|}{ Religion $^{\mathrm{b}}$} \\
\hline Muslim & 119 & 83.8 \\
\hline Buddhist & 8 & 5.6 \\
\hline Hindu & 11 & 7.7 \\
\hline Christian & 2 & $\mathrm{I} .4$ \\
\hline \multicolumn{3}{|c|}{ Educational characteristics } \\
\hline \multicolumn{3}{|c|}{ Year of study } \\
\hline Year III & 41 & 28.9 \\
\hline Year IV & 55 & 38.7 \\
\hline Year V & 45 & 31.7 \\
\hline \multicolumn{3}{|l|}{ Type of foundation studyc } \\
\hline One-year matriculation & III & 78.2 \\
\hline Two-year matriculation & 2 & 1.4 \\
\hline Others & 24 & 16.9 \\
\hline
\end{tabular}

Notes: ${ }^{a}$ missing data; ${ }^{\mathrm{2}} 2$ missing data; ${ }^{\mathrm{c}} 5$ missing data. 
if you are not sure about your diagnosis" $(26 \%, 37)$, "planning to streamline/stop the antibiotic treatment according to the clinical evaluation and investigations" $(31 \%, 44)$, and "planning the duration of the antibiotic treatment" $(35 \%, 49)$.
The detailed results are shown in Table 2. There were no significant differences $(P>0.05)$ observed in any of parameters of confidence of antibiotic prescribing between year and the sex of the respondents (Tables 3 and 4).

Table 2 Levels of confidence in different areas of antibiotic prescribing $(n=\mid 42)$

\begin{tabular}{|c|c|c|c|c|}
\hline \multirow{2}{*}{$\begin{array}{l}\text { Level of confidence- } \\
\text { based on domain }\end{array}$} & \multicolumn{3}{|c|}{ Number of respondents, $\mathrm{n}(\%)$} & \multirow[t]{2}{*}{ Total } \\
\hline & Year III & Year IV & Year V & \\
\hline \multicolumn{5}{|c|}{ Making an accurate diagnosis of infection/sepsis } \\
\hline Very unconfident & $0(0)$ & I (I.8) & $0(0)$ & I (0.7) \\
\hline Unconfident & $8(19.5)$ & $10(18.2)$ & $3(6.7)$ & $21(14.8)$ \\
\hline Confident & $27(65.9)$ & 35 (63.6) & $32(71.1)$ & $95(66.9)$ \\
\hline Very confident & $4(9.8)$ & $6(10.9)$ & $9(20.0)$ & $19(13.4)$ \\
\hline Uncertain & $2(4.9)$ & $3(5.5)$ & $\mathrm{I}(2.2)$ & $6(4.2)$ \\
\hline \multicolumn{5}{|c|}{ Interpreting microbiological results } \\
\hline Very unconfident & I (2.4) & $\mathrm{I}(\mathrm{I} .8)$ & $0(0)$ & $2(1.4)$ \\
\hline Unconfident & $12(29.3)$ & $18(32.7)$ & $6(13.3)$ & $36(25.4)$ \\
\hline Confident & $20(48.8)$ & $26(47.3)$ & 31 (68.9) & 78 (54.9) \\
\hline Very confident & $5(12.2)$ & $7(12.7)$ & $7(15.6)$ & $19(3.4)$ \\
\hline Uncertain & $3(7.3)$ & $3(5.5)$ & I (2.2) & $7(4.9)$ \\
\hline \multicolumn{5}{|c|}{ Choosing the correct antibiotic } \\
\hline Very unconfident & I (2.4) & I (I.8) & $0(0)$ & $2(1.4)$ \\
\hline Unconfident & $10(24.4)$ & $21(38.2)$ & $10(22.2)$ & $42(29.6)$ \\
\hline Confident & 24 (58.5) & $26(47.3)$ & $28(62.2)$ & 78 (54.9) \\
\hline Very confident & $6(14.6)$ & $5(9.1)$ & $6(13.3)$ & $17(12.0)$ \\
\hline Uncertain & $0(0)$ & $2(3.6)$ & I (2.2) & $3(2.1)$ \\
\hline \multicolumn{5}{|c|}{ Choosing the correct dose and interval of administration } \\
\hline Very unconfident & I (2.4) & I (I.8) & I (2.2) & $3(2.8)$ \\
\hline Unconfident & $15(36.6)$ & $24(43.6)$ & $21(46.7)$ & $60(42.3)$ \\
\hline Confident & $22(53.7)$ & $20(36.4)$ & $17(37.8)$ & $59(4 I .5)$ \\
\hline Very confident & $2(4.9)$ & $5(9.1)$ & $3(6.7)$ & $10(7.0)$ \\
\hline Uncertain & I (2.4) & $5(9.1)$ & $3(6.7)$ & $9(6.3)$ \\
\hline \multicolumn{5}{|c|}{ Using a combination therapy if appropriate } \\
\hline Very unconfident & I (2.4) & $2(3.6)$ & $0(0)$ & $4(2.8)$ \\
\hline Unconfident & $14(34.1)$ & $26(47.3)$ & $17(37.8)$ & $57(40.1)$ \\
\hline Confident & $22(53.7)$ & $19(34.5)$ & $22(48.9)$ & $63(44.4)$ \\
\hline Very confident & $3(7.3)$ & $6(10.9)$ & $4(8.9)$ & $13(9.2)$ \\
\hline Uncertain & I (2.4) & $2(3.6)$ & $2(4.4)$ & $5(3.5)$ \\
\hline \multicolumn{5}{|c|}{ Choosing between intravenous and oral administration } \\
\hline Very unconfident & $0(0)$ & I (I.8) & $0(0)$ & I (0.7) \\
\hline Unconfident & $15(36.6)$ & $9(16.4)$ & $8(17.8)$ & $32(22.5)$ \\
\hline Confident & $16(39.0)$ & $34(61.8)$ & $28(62.2)$ & $79(55.6)$ \\
\hline Very confident & $8(19.5)$ & $10(18.2)$ & $8(17.8)$ & $26(18.3)$ \\
\hline Uncertain & $2(4.9)$ & I (I.8) & I (2.2) & $4(2.8)$ \\
\hline \multicolumn{5}{|c|}{ Deciding not to prescribe an antibiotic if the patient has a fever, but no severity criteria, and if you are not sure about your } \\
\hline \multicolumn{5}{|c|}{ diagnosis $^{\mathrm{a}}$} \\
\hline Very unconfident & $0(0)$ & $2(3.6)$ & $0(0)$ & $2(1.4)$ \\
\hline Unconfident & $12(29.3)$ & $16(29.1)$ & $9(20.0)$ & $37(26.1)$ \\
\hline Confident & $23(56.1)$ & $25(45.5)$ & $30(66.7)$ & $79(55.6)$ \\
\hline Very confident & $4(9.8)$ & $6(10.9)$ & $3(6.7)$ & $13(9.2)$ \\
\hline Uncertain & $2(4.9)$ & $5(9.1)$ & $3(6.70)$ & $10(7.0)$ \\
\hline \multicolumn{5}{|c|}{ Planning to streamline/stop the antibiotic treatment, according to clinical evaluation and investigations } \\
\hline Very unconfident & $0(0)$ & $0(0)$ & $0(0)$ & $0(0)$ \\
\hline Unconfident & $13(3 \mid .7)$ & $19(34.5)$ & $12(26.7)$ & $44(31.0)$ \\
\hline Confident & 18 (43.9) & $24(43.6)$ & $29(64.4)$ & $72(50.7)$ \\
\hline Very confident & $9(22.0)$ & $5(9.1)$ & $2(4.4)$ & $16(11.3)$ \\
\hline Uncertain & I (2.4) & $7(12.7)$ & $2(4.4)$ & $10(7.0)$ \\
\hline \multicolumn{5}{|c|}{ Planning the duration of the antibiotic treatment } \\
\hline Very unconfident & I (2.4) & $2(3.6)$ & $\mathrm{I}(2.2)$ & $4(2.8)$ \\
\hline Unconfident & $14(34.1)$ & $16(29.1)$ & $18(40.0)$ & $49(34.5)$ \\
\hline Confident & $21(51.2)$ & $24(43.6)$ & $24(53.3)$ & $69(48.6)$ \\
\hline Very confident & $5(12.2)$ & $8(14.5)$ & $2(4.4)$ & $15(10.6)$ \\
\hline Uncertain & $0(0)$ & $5(9.1)$ & $0(0)$ & $5(3.5)$ \\
\hline
\end{tabular}

Notes: The highest frequency is bold. ${ }^{\text {a }}$ s missing data. 
Table 3 Comparison among Year III, IV, and V in levels of confidence of antibiotic prescribing

\begin{tabular}{|c|c|c|c|c|c|c|}
\hline & \multirow{2}{*}{$\begin{array}{l}\text { Areas of confidence in } \\
\text { prescribing }\end{array}$} & \multicolumn{3}{|l|}{ Mean (SD) } & \multirow[t]{2}{*}{ F stat } & \multirow[t]{2}{*}{$P$-value* } \\
\hline & & Year III & Year IV & Year V & & \\
\hline I & Making accurate diagnosis of infection & $3.00(0.7 I)$ & $3.00(0.77)$ & $3.18(0.58)$ & 0.67 & 0.571 \\
\hline 2 & Decide not to prescribe antibiotic & $2.90(0.77)$ & $21.04(134.31)$ & $3.00(0.74)$ & 0.52 & 0.669 \\
\hline 3 & Choose correct antibiotic & $2.85(0.69)$ & $2.75(0.80)$ & $2.96(0.67)$ & 1.13 & 0.339 \\
\hline 4 & Choose correct dose & $2.68(0.72)$ & $2.80(0.97)$ & $2.69(0.90)$ & 1.46 & 0.228 \\
\hline 5 & Use combine therapy & $2.73(0.74)$ & $2.64(0.87)$ & $2.80(0.79)$ & 1.84 & 0.143 \\
\hline 6 & Choose route of administration & $2.93(0.88)$ & $3.02(0.7 I)$ & $3.04(0.67)$ & 0.19 & 0.901 \\
\hline 7 & Interpret microbe result & $2.93(0.91)$ & $2.87(0.86)$ & $3.07(0.62)$ & 0.50 & 0.686 \\
\hline 8 & Planning to stop antibiotic & $2.95(0.8 \mathrm{I})$ & $3.00(0.98)$ & $2.87(0.69)$ & 0.21 & 0.891 \\
\hline 9 & Planning duration of antibiotic & $2.73(0.7 \mathrm{I})$ & $2.96(0.98)$ & $2.60(0.62)$ & 2.08 & 0.106 \\
\hline
\end{tabular}

Note: *One-way analysis of variance.

Abbreviation: SD, standard deviation.

\section{Training in antibiotic prescribing}

The majority $(88 \%, 124)$ of the study participants stated that they would like more training in the antibiotic selection, seven students (5\%) did not want further education, and another eleven students ( $8 \%$ ) were unsure. Most of the respondents $(87 \%, 123)$ felt prescribing inappropriate or unnecessary antibiotics to be professionally unethical. In all, $72 \%$ (102) of the respondents were confident that their current teaching Hospital Sultanah Nur Zahirah (HSNZ) has antibiotic guidelines, but 23\% (33) students were unaware, and 5\% (7) students indicated that there are no antibiotic guidelines for HSNZ. In all, 50\% (71) of the respondents do not possess a copy of HSNZ antibiotic guidelines or found it on the internet while $34 \%$ (48) of students said they received a copy and 16\% (23) students were unsure about it. Personally consulting antibiotic guidelines when considering an antibiotic for a patient was only practiced by $45 \%$ (64) students, and the rest, 39\% (56) and 16\% (22) students, were either not practiced or unsure (Figure 1). There were statistically $(P=0.018)$ significant differences observed among Year of Study of the respondents regarding the question "How many hours of training in the principles of prudent antibiotic use do you think you have received during your undergraduate study?"

\section{Knowledge that may shape perceptions of $A R$}

Most students $(83 \%, 118)$ felt that antibiotic resistance was a national problem, and 63\% (90) felt that the situation also exists in the teaching hospital (Figure 2). In all, $42 \%$ (59) of respondents stated that methicillin-resistant Staphylococcus aureus was responsible for a greater proportion $(21 \%-40 \%)$ of S. aureus bacteremia in Malaysia, while 35\% (50) respondents stated that it was $<1 \% 10$ years ago. In all, $49 \%$ (65) respondents thought that over $1 \%-20 \%$ of $S$. aureus bacteremias were caused by vancomycin-resistant bacteria in Malaysia, and 40\% (57) respondents believed that over $21 \%-40 \%$ of all bacterial infections in Malaysia (excluding TB) were resistant to all known antibiotics (Figure 3). There were no significant differences $(P>0.05)$ observed in any of parameters regarding knowledge that may shape the perception of AR between year and sex of the respondents.

Table 4 Comparison between sexes in levels of confidence of antibiotic prescribing

\begin{tabular}{|c|c|c|c|c|c|c|}
\hline & \multirow{2}{*}{$\begin{array}{l}\text { Areas of confidence in } \\
\text { prescribing }\end{array}$} & \multicolumn{2}{|l|}{ Mean (SD) } & \multirow{2}{*}{$\frac{\text { Mean difference }}{(95 \% \mathrm{CI})}$} & \multirow[t]{2}{*}{ t-stat (df) } & \multirow[t]{2}{*}{ P-value* } \\
\hline & & Male & Female & & & \\
\hline I & Making accurate diagnosis of infection & $3.18(0.64)$ & $3.01(0.71)$ & $0.17(-0.09,0.42)$ & $1.28(140)$ & 0.202 \\
\hline 2 & Decide not to prescribe antibiotic & $3.03(0.86)$ & $12.68(98.63)$ & $-9.65(-40.55,21.25)$ & $-0.62(140)$ & 0.538 \\
\hline 3 & Choose correct antibiotic & $2.93(0.76)$ & $2.8(0.72)$ & $0.12(-0.15,0.39)$ & $0.89(140)$ & 0.376 \\
\hline 4 & Choose correct dose & $2.75(0.98)$ & $2.71(0.85)$ & $0.04(-0.28,0.37)$ & $0.27(140)$ & 0.791 \\
\hline 5 & Use combine therapy & $2.75(0.90)$ & $2.69(0.78)$ & $0.06(-0.24,0.37)$ & $0.42(140)$ & 0.677 \\
\hline 6 & Choose route of administration & $3.00(0.75)$ & $3.00(0.75)$ & $0(-0.28,0.28)$ & $0.00(140)$ & 1.000 \\
\hline 7 & Interpret microbe result & $3.00(0.60)$ & $2.93(0.87)$ & $0.07(-0.19,0.32)$ & $0.54(103.02)$ & 0.593 \\
\hline 8 & Planning to stop antibiotic & $2.98(0.83)$ & $2.93(0.85)$ & $0.04(-0.27,0.36)$ & $0.28(140)$ & 0.782 \\
\hline 9 & Planning duration of antibiotic & $2.75(0.87)$ & $2.78(0.79)$ & $-0.03(-0.34,0.27)$ & $-0.23(140)$ & 0.822 \\
\hline
\end{tabular}

Note: *Independent $t$-test.

Abbreviations: $\mathrm{SD}$, standard deviation; $\mathrm{Cl}$, confidence interval. 


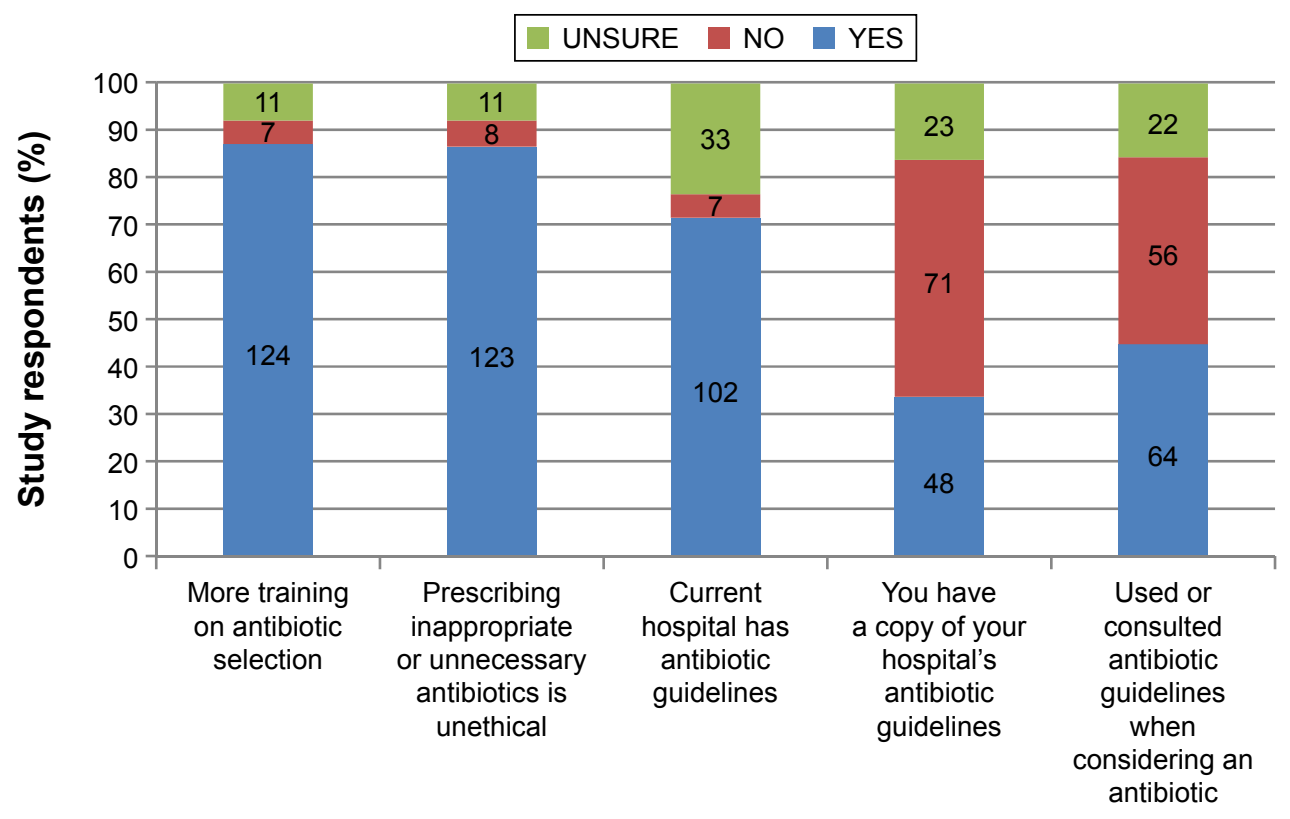

Figure I Questions on training in antibiotic prescribing.

\section{Antibiotic usage}

About 35\% (49) of the respondents felt that the proportion of all clinical antibiotic use in a hospital in Malaysia comprised of $41 \%-60 \%$ of cases when compared to the community. In all, $37 \%$ (52) of the respondents agreed that the clinical antibiotic usage in this country is probably unnecessary or inappropriate by $1 \%-20 \%$ (Figure 4 ).

\section{Contributors to resistance}

The majority of the respondents agreed that "too many antibiotic prescriptions" $(55 \%, 78)$, "too many broad spectrum antibiotics used" $(50 \%, 71)$, and "excessive use of antibiotics in livestock" $(43 \%, 61)$ were leading contributors to AR (Table 5). Another group felt that "too long durations of antibiotic treatment" $(42 \%, 59)$, "dosing of antibiotics are too low" $(36 \%, 51)$, "poor hand hygiene" $(27 \%, 38)$, "not removing the focus of infection" $(41 \%, 58)$, and "paying too much attention to pharmaceutical representatives/advertising" $(37 \%, 53)$ were moderately important factors contributing to AR (Table 5). The rest of the study participants gave the opinion for slightly important and not important contributors to generate AR (Table 5). There were no significant differences $(P>0.05)$ observed in any of parameters of confidence of antibiotic prescribing between years and the sex of the respondents (Tables 6 and 7).

\section{Development of antibiotics}

In all, $44 \%$ (63) of the respondents believed that six to ten antibiotic classes were available during the period 1980-2011, and 23\% (45) of students thought that there would be six to ten new antibiotic classes in 2011-2020 (Figure 5).

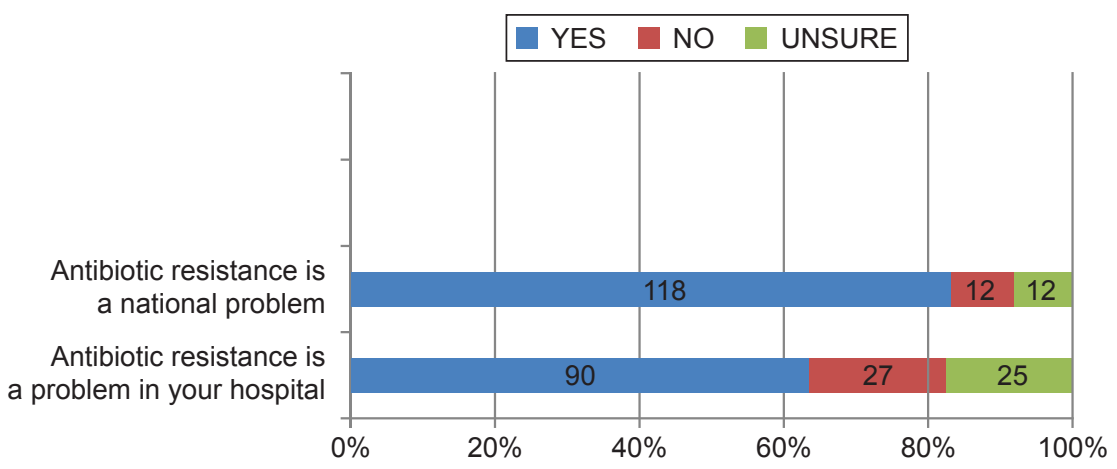

Figure 2 Students' perceptions of antimicrobial resistance. 


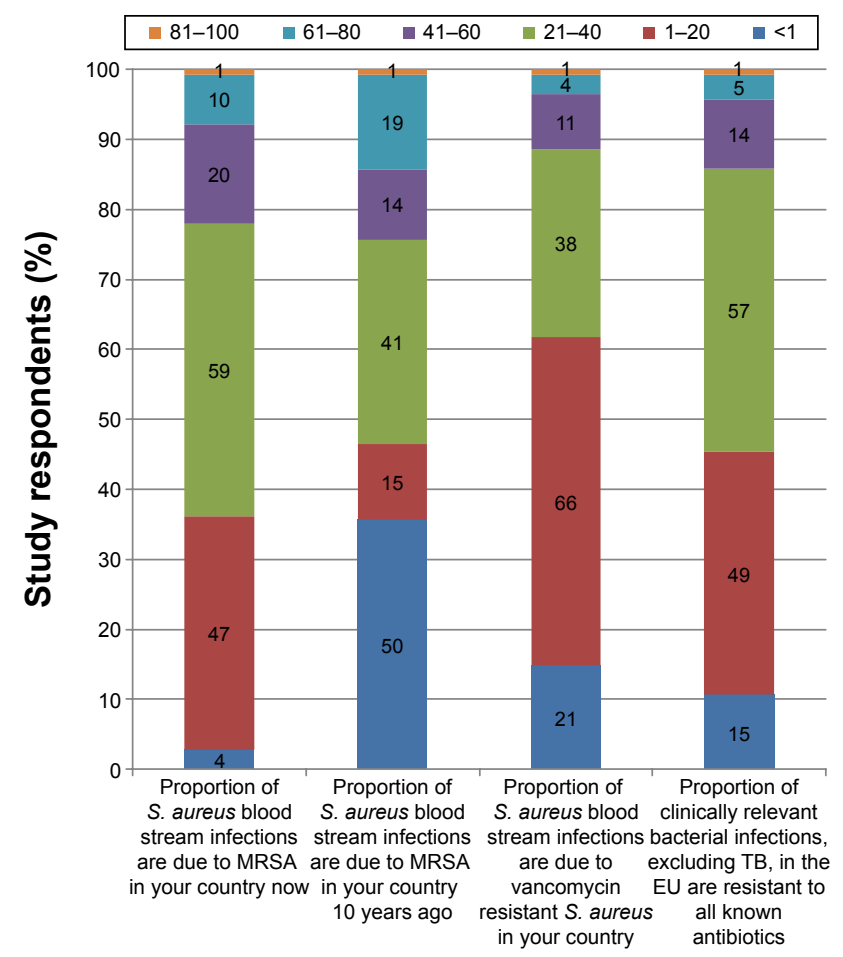

Figure 3 Knowledge of students that may shape perceptions of antimicrobial resistance.

Abbreviations: EU, European Union; MRSA, methicillin-resistant Staphylococcus aureus; S. aureus, Staphylococcus aureus; TB, tuberculosis.

\section{Perceptions of AR}

Resistant bacteria are believed to cause 25,000 deaths per year in Europe. ${ }^{79}$ Road traffic accidents (RTAs) and lung cancer are responsible for around two to three and ten times as many deaths, respectively. ${ }^{80}$ Overall, 27\% (38) and 36\% (51) of research participants think that deaths due to AR were four to eight times higher than RTA and lung cancer, respectively (Figure 6). In all, 23\% (33) medical students in the study were able to answer correctly for estimation of RTAs while $36 \%$ (51) answered correctly the reasonable estimate for comparison between deaths due to lung cancer and AR. Most of the respondents $(45 \%, 65)$ felt that the antibiotics they would prescribe as doctors would likely contribute to the problem of AR later, and $42 \%$ (60) students believed that antibiotic resistance would become a possible clinical problem during their career.

\section{Discussion}

\section{Demographic profile}

The response rate of the students for the current study was $86 \%$, which is very similar to that of a Danish recommendation. ${ }^{81}$ Universal sampling was adopted because of small population size (179) and 15 of them participated in the pilot study. Consequently, 164 was the total population to whom the questionnaire was distributed; among them, 142 (86\%) returned and 22 did not participate in the study. The study respondents are able to enjoy complete freedom to participate or not. Hence, it is hard to answer why they did not return the questionnaire. Furthermore, a total of $157(15+142)$ joined the current work. So, actually among 179 clinical students of UniSZA, 88\% participated in this cross-sectional research. In this study, there were more female medical students than male colleagues; this finding is analogous to that in many other studies. ${ }^{75-78,82-84}$

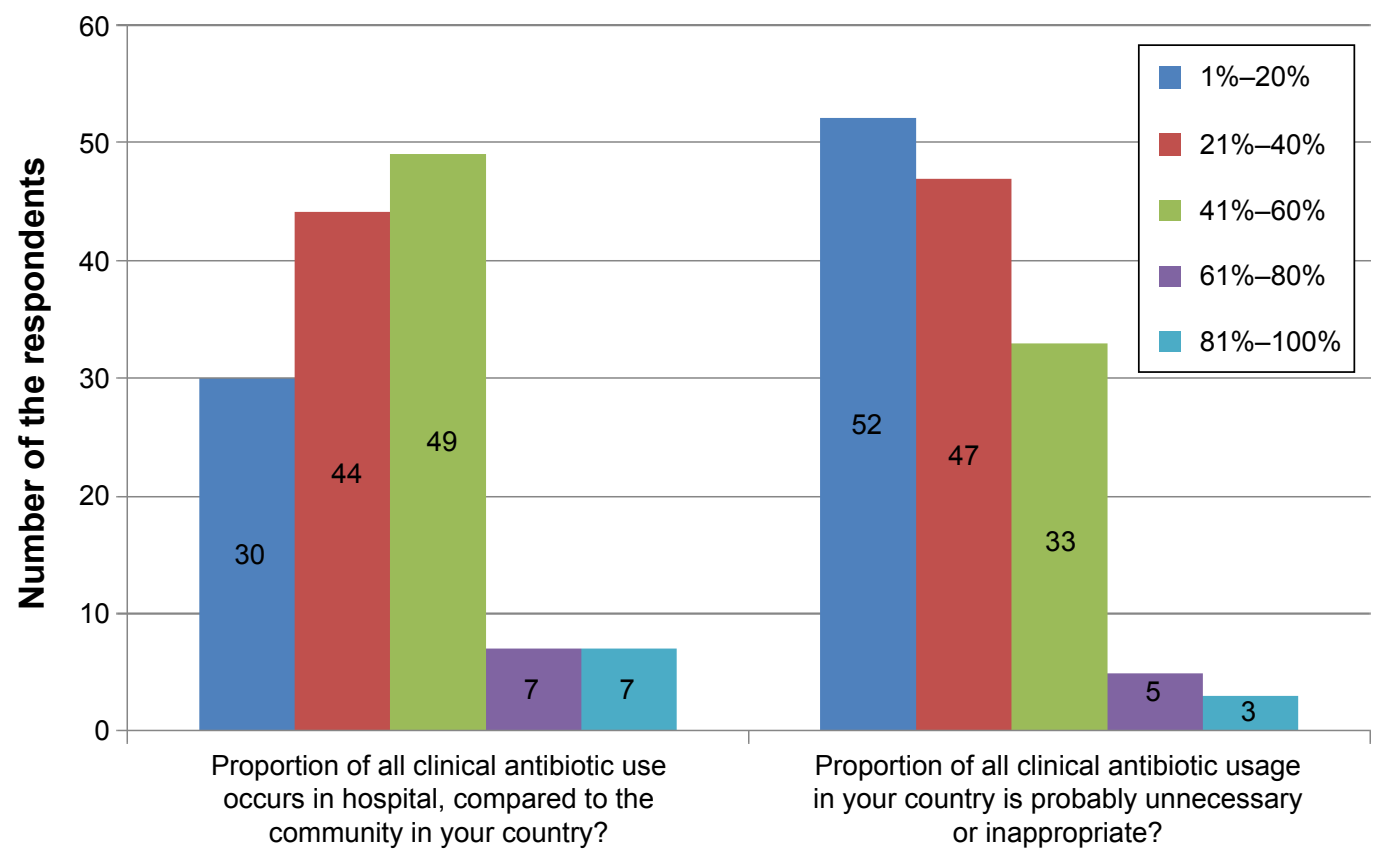

Figure 4 Knowledge of proportion of all clinical antibiotic usage. 
Table 5 Perceptions of the importance of potential contributors to antibiotic resistance $(n=142)$

\begin{tabular}{|c|c|c|c|c|}
\hline \multirow[t]{2}{*}{ Statements } & \multicolumn{4}{|c|}{ Number of respondent, $\mathrm{n}(\%)$} \\
\hline & $\begin{array}{l}\text { Very } \\
\text { important }\end{array}$ & $\begin{array}{l}\text { Moderately } \\
\text { important }\end{array}$ & $\begin{array}{l}\text { Slightly } \\
\text { important }\end{array}$ & $\begin{array}{l}\text { Not } \\
\text { important }\end{array}$ \\
\hline Too many antibiotic prescriptions & $78(54.9)$ & $47(33.1)$ & $14(9.9)$ & $3(2.1)$ \\
\hline Too many broad spectrum antibiotics used & $71(50.0)$ & $51(35.9)$ & $16(11.3)$ & $4(2.8)$ \\
\hline Too long durations of antibiotic treatment ${ }^{\mathrm{a}}$ & $43(30.3)$ & $59(4 I .5)$ & $30(2 I .1)$ & $9(6.3)$ \\
\hline Dosing of antibiotics are too low & $29(20.4)$ & $51(35.9)$ & $50(35.2)$ & $12(8.5)$ \\
\hline Excessive use of antibiotics in livestock & $6 I(43.0)$ & $45(31.7)$ & $28(19.7)$ & $8(5.6)$ \\
\hline Poor hand hygiene & $31(21.8)$ & $38(26.8)$ & $37(26.1)$ & $36(25.4)$ \\
\hline Not removing the focus of infection (eg, medical devices or catheters) & $53(37.3)$ & $58(40.8)$ & $24(16.9)$ & $7(4.9)$ \\
\hline Paying too much attention to pharmaceutical representatives/advertising ${ }^{b}$ & $31(21.8)$ & $53(37.3)$ & $35(24.6)$ & $21(14.8)$ \\
\hline
\end{tabular}

Notes: The highest frequency is bold. al missing data; ${ }^{\mathrm{b}} 2$ missing data.

Table 6 Comparison among Year III, IV, and V in levels of contributors to resistance

\begin{tabular}{|c|c|c|c|c|c|c|}
\hline & \multirow[t]{2}{*}{ Contributors to resistance } & \multicolumn{3}{|l|}{ Mean (SD) } & \multirow[t]{2}{*}{ F stat } & \multirow[t]{2}{*}{$P$-value* } \\
\hline & & Year III & Year IV & Year V & & \\
\hline I & Too many antibiotic prescriptions & $\mathrm{I} .73(0.78)$ & I.5I (0.77) & $1.58(0.72)$ & 0.90 & 0.444 \\
\hline 2 & Too many broad spectrums used & $\mathrm{I} .73(0.78)$ & I.7I (0.88) & $1.58(0.69)$ & 0.57 & 0.635 \\
\hline 3 & Too long duration & $2.15(0.79)$ & $20.25(134.42)$ & $1.84(0.85)$ & 0.53 & 0.662 \\
\hline 4 & Dosing too low & $2.44(0.74)$ & $2.25(0.95)$ & $2.31(0.95)$ & 1.07 & 0.364 \\
\hline 5 & Excessive use of antibiotics & $1.95(0.87)$ & $1.93(0.94)$ & $1.78(0.95)$ & 0.62 & 0.605 \\
\hline 6 & Poor hand hygiene & $2.29(1.06)$ & $2.55(1.05)$ & $2.76(1.15)$ & 1.90 & 0.132 \\
\hline 7 & Not removing focus of infection & $2.07(0.85)$ & $1.89(0.94)$ & $1.76(0.74)$ & 1.36 & 0.256 \\
\hline 8 & Pay too much on attention advertising & $26.4 I(155.69)$ & $20.42(134.40)$ & $2.56(0.97)$ & 0.33 & 0.806 \\
\hline
\end{tabular}

Note: *One-way analysis of variance.

Abbreviation: SD, standard deviation.

Table 7 Comparison between sexes on their view regarding contributors to resistance

\begin{tabular}{|c|c|c|c|c|c|c|}
\hline & \multirow[t]{2}{*}{ Contributors to resistance } & \multicolumn{2}{|l|}{ Mean (SD) } & \multirow{2}{*}{$\begin{array}{l}\text { Mean difference } \\
(95 \% \mathrm{CI})\end{array}$} & \multirow[t]{2}{*}{$t$-stat $(d f)$} & \multirow[t]{2}{*}{$P$-value* } \\
\hline & & Male & Female & & & \\
\hline I & Too many antibiotic prescriptions & $1.68(0.80)$ & $1.56(0.74)$ & $0.12(-0.16,0.4)$ & $0.82(140)$ & 0.411 \\
\hline 2 & Too many broad spectrums used & $1.80(0.91)$ & I.62 (0.73) & $0.18(-0.11,0.47)$ & $1.24(140)$ & 0.216 \\
\hline 3 & Too long duration & $26.98(157.63)$ & $2.03(0.92)$ & $24.95(-25.47,75.36)$ & $1.00(39.00)$ & 0.323 \\
\hline 4 & Dosing too low & $2.38(0.84)$ & $2.29(0.92)$ & $0.08(-0.25,0.4 I)$ & $0.48(140)$ & 0.629 \\
\hline 5 & Excessive use of antibiotics & $1.90(0.84)$ & I.87 (0.95) & $0.03(-0.3 \mathrm{I}, 0.37)$ & $0.16(140)$ & 0.873 \\
\hline 6 & Poor hand hygiene & $2.50(1.06)$ & $2.57(\mathrm{I} . \mathrm{II})$ & $-0.07(-0.47,0.34)$ & $-0.34(140)$ & 0.738 \\
\hline 7 & Not removing focus of infection & $\mathrm{I} .85(0.80)$ & I.9I (0.88) & $-0.06(-0.38,0.26)$ & $-0.39(140)$ & 0.701 \\
\hline 8 & Pay too much attention on advertising & $2.38(0.98)$ & $21.85(138.88)$ & $-19.48(-62.99,24.03)$ & $-0.89(140)$ & 0.378 \\
\hline
\end{tabular}

Note: *Independent $t$-test.

Abbreviation: SD, standard deviation.

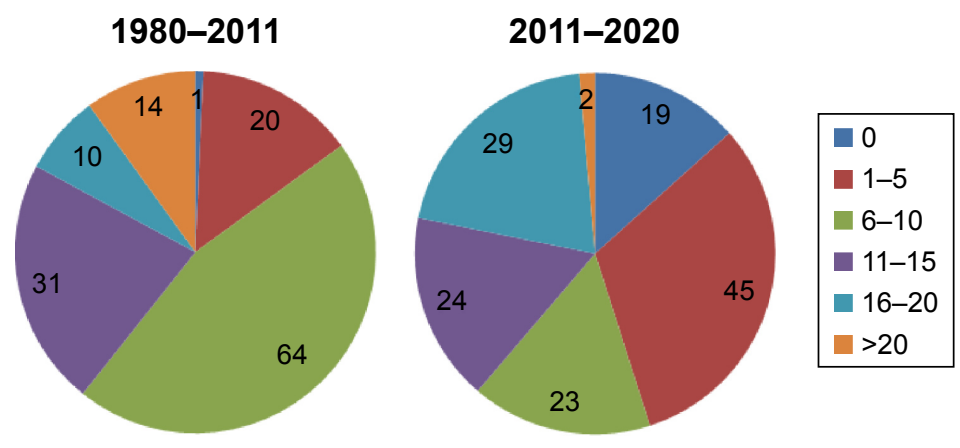

Figure $5 \mathrm{New}$ classes of antibiotics that students think became clinically available at years I980-20II and 20I I-2020. 


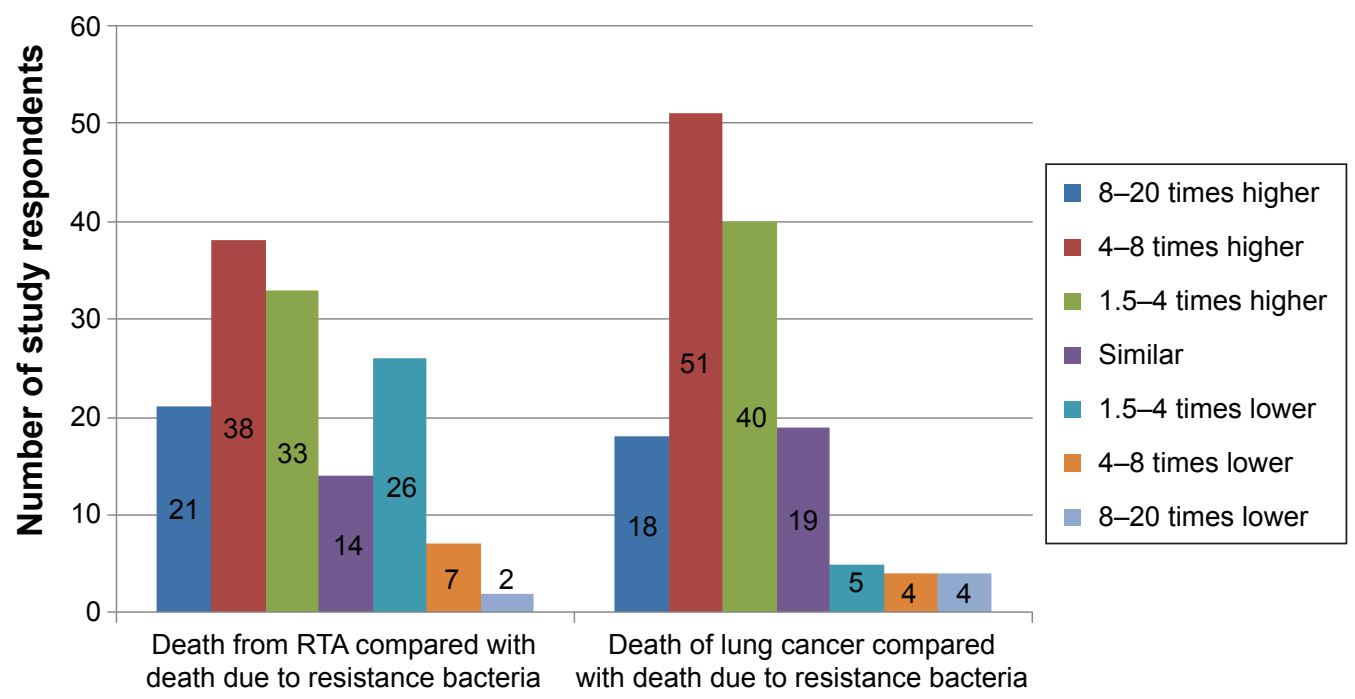

Figure 6 Student's perception of death from road traffic accidents and lung cancer compared with death due to bacterial resistance to antimicrobials. Abbreviation: RTA, road traffic accident.

\section{Levels of confidence in prescribing}

The participants felt more confident in "making an accurate diagnosis of infection/sepsis" (67\%), "interpreting microbiological results" (55\%), "choosing the correct antibiotic" (55\%), "choosing the correct dose and interval of administration" ( $42 \%)$, "using a combination therapy if appropriate" (44\%), "choosing between intravenous and oral administration" (56\%), "deciding not to prescribe an antibiotic if the patient has fever, but no severity criteria, and if you are not sure about your diagnosis" (56\%), "planning to streamline/stop the antibiotic treatment according to the clinical evaluation and investigations" (51\%), and "planning the duration of the antibiotic treatment" (49\%). Overall, $50 \%$ or more of current study participants were confident of six of nine issues of the level of confidence in prescribing. Current study findings regarding knowledge level of antibiotic prescribing and resistance were not satisfactory, but research participants were medical students of Years III-V. Again, at UniSZA, from year III, students are first exposed to the hospital and patients. As in first 2 years, they go to preclinical subjects with only little early clinical exposure. Therefore, study participants have at least 3 months to 2 years and 3 months extra time to learn more regarding antibiotic prescribing in their clinical years. Moreover, after graduation, according to Malaysian regulations, they will be working as a house officer for another 2 years under strict supervision. Consequently, there is time for improvement. Our study findings were lower than some European studies and Bangladeshi studies conducted on interns or house officers. ${ }^{65,85-87}$ But regarding "using a combination therapy if appropriate," our respondents obtain an almost similar score to the studies, although our participants were medical students and those were trainee doctors. ${ }^{85,87}$

\section{Training in antibiotic prescribing}

The majority ( $88 \%$ ) of the respondents stated that they would like more training on antibiotic selection. Most of the respondents $(87 \%)$ felt prescribing antibiotics irrationally was unethical. About $72 \%$ of study respondents were sure that HSNZ had antibiotic guidelines, but $50 \%$ of them did not possess a copy of the guide, and only $45 \%$ had consulted the antibiotic guidelines (Figure 1). Study findings showed that the respondents have realized there is a gap between their theoretical lecture-based input, ${ }^{72}$ regarding antimicrobials, and clinical practice. Similar studies from different countries also indicated demand for more educational intervention. ${ }^{55-65,70,87}$ The total antimicrobials class hours at the faculty of medicine is 7 hours during the first 2 years of the preclinical stage. All are lecture-based teaching hours. UniSZA's medical curriculum does not currently possess any class for teaching antimicrobial selection. Therefore, students when started clinical clerking they comprehend that there is an urgent need for training of drug, including antimicrobial selection procedure.

\section{Knowledge that may shape perceptions of AR}

Most students (83\%) felt that antibiotic resistance is a national problem, and $63 \%$ felt that the situation also exists in HSNZ (Figure 2). In all, $42 \%$ of our medical students stated that $21 \%-40 \%$ S. aureus infections were due to methicillin-resistant Staphylococcus aureus while 35\% 
thought it was $<1 \% 10$ years ago. In all, $49 \%$ research participants thought that over $1 \%-20 \%$ of $S$. aureus bacteremias were caused by vancomycin-resistant bacteria in Malaysia, and $40 \%$ students believed that over $21 \%-40 \%$ of all bacterial infections in Malaysia (excluding TB) were resistant to all known antibiotics (Figure 3). These findings were more or less similar to Bangladeshi and European studies. ${ }^{85,87}$

\section{Antibiotic usage}

About $35 \%$ and $23 \%$ of the research participants thought that $41 \%-60 \%$ antimicrobials used in hospitals in Malaysia and the antibiotic chosen were inappropriate (Figure 4). Current study findings regarding antimicrobial usage in the hospital are lower than the US study ${ }^{23}$ but the irrational use of antibiotics was quite similar to a number of studies. ${ }^{25-28}$

\section{Contributors to resistance}

The majority of this study respondents agreed that "too many antibiotic prescriptions" (55\%), "too many broad spectrum antibiotics used" (50\%), and "excessive use of antibiotics in livestock" (43\%) were primary contributors to AR (Table 5). These findings were similar to some studies conducted in different parts of the world.$^{85,88-90}$ Another group felt that "too long durations of antibiotic treatment" (42\%), "dosing of antibiotics are too low" (36\%), "poor hand hygiene" (27\%), "not removing the focus of infection" $(41 \%, 58)$, and "paying too much attention to pharmaceutical representatives/advertising" (37\%) were moderately important factors contributing to AR (Table 5). A good number of research participants were quite aware of poor hand hygiene as a contributor to AR. A lot of studies have reported that poor hand hygiene contributes to AR. ${ }^{90-92}$ Since our respondents were still students and remain within the university, they have yet to be exposed to the persuasions of the pharmaceutical industries. ${ }^{76,87,93}$

\section{Development of antibiotics}

In all, $45 \%$ and $32 \%$ of the research participants believed that six to ten and eleven to 15 antibiotic classes became available during the period 1980-2011 and 2011-2020, respectively (Figure 5). The present study findings were different from a European study. In this study, respondents believed that more antimicrobials were available during 2011-2020. ${ }^{65}$

\section{Perceptions of AR}

About $23 \%$ and $10 \%$ of research participants think that death due to RTA and lung cancer is four to five and eight to 20 times higher than AR, respectively (Figure 6). These findings were only $9 \%$ in a multicenter European study ${ }^{65}$ Research respondents (10-13\%) thought that death due to RTA and lung cancer were similar with AR but a European study reported that $51 \%$ of study respondents believed there are similar mortality numbers in AR, RTA and lung cancer (Figure 6). ${ }^{65}$

\section{Limitation of the study}

This is a cross-sectional study. Therefore, the findings are only the snapshot of the current clinical batches of medical students in UniSZA, Malaysia. Again, the sample size was small because the UniSZA MBBS program has only 179 clinical medical students. Therefore, it will be difficult to generalize the findings for the whole country.

\section{Conclusion}

Taking into account the limitation of a cross-sectional study, this study was able to find the prevailing perception of respondents regarding antimicrobial prescribing and resistance. This research has evidently concluded that there is a gap between theoretical input and clinical practice. Students have demanded more educational intervention to face this potential threat of AR. Clinical competency regarding antibiotic prescribing during their housemanship was mainly acquired by emulating senior colleagues, and this should be replaced by $\mathrm{P}$-drug selection program in the MBBS curriculum and also during housemanship. Both national and local guidelines for antibiotic prescribing should be made available more easily, preferably as a free download from the university or hospital website. Moreover, care must be taken to update the guidelines regularly. In summary, AR is a multifactorial problem. Therefore, much integration and cooperation among all health professionals, including patients, is needed to eliminate and reduce the risk of bacterial resistance developing to antimicrobials.

\section{Acknowledgments}

The authors are much grateful to all participating medical students of Faculty of Medicine, UniSZA, Malaysia. The authors would like to extend their sincere thanks to Seraj Zohurul Haque, Year IV medical student, Faculty of Medicine, University of Dundee, Dundee DD1 4HN, Scotland, UK. As a final point, we express our gratitude to Dr Mohd Afandi bin Muhamad, Malaysia, for his comment and notes. This study has obtained no funding.

\section{Disclosure}

The authors report no conflicts of interest in this work.

\section{References}

1. Clardy J, Fischbach MA, Currie CR. The natural history of antibiotics Curr Biol. 2009;19(11):R437-R441. 
2. American Chemical Society. The Discovery and Development of Penicillin 1928-1948. International Historic Chemical Landmark. Washington, DC: ACS; 1999. Available from: http://www.acs. org/content/dam/acsorg/education/whatischemistry/landmarks/ flemingpenicillin/the-discovery-and-development-of-penicillincommemorative-booklet.pdf. Accessed November 10, 2015.

3. Diggins F. The true history of the discovery of penicillin by Alexander Fleming. Biomed Sci. 2003;246-249.

4. Peláez F. The historical delivery of antibiotics from microbial natural products - can history repeat? Biochem Pharmacol. 2006;71(7): 981-990.

5. Saga T, Yamaguchi K. History of antimicrobial agents and resistant bacteria. JMAJ. 2009;52(2):103-108.

6. Bassett EJ, Keith MS, Armelagos GJ, Martin DL, Villanueva AR. Tetracycline-labeled human bone from ancient Sudanese Nubia (A.D. 350). Science. 1980;209:1532-1534.

7. Nelson ML, Dinardo A, Hochberg J, Armelagos GJ. Brief communication: mass spectroscopic characterization of tetracycline in the skeletal remains of an ancient population from Sudanese Nubia 350-550 CE. Am J Phys Anthropol. 2010;143:151-154.

8. Cook M, Molto E, Anderson C. Fluorochrome labelling in Roman period skeletons from Dakhleh Oasis, Egypt. Am J Phys Anthropol. 1989;80: 137-143.

9. Armelagos GJ. Disease in ancient Nubia. Science. 1969;163:225-258.

10. Borgdorff MW, van Soolingen D. The re-emergence of tuberculosis: what have we learnt from molecular epidemiology? Clin Microbiol Infect. 2013;19(10):889-901.

11. Delogu G, Sali M, Fadda G. The biology of mycobacterium tuberculosis infection. Mediterr J Hematol Infect Dis. 2013;5(1):e2013070.

12. Sohail M. Tuberculosis: A re-emerging enemy. J Mol Genet Med. 2006;2(1):87-88.

13. World Health Organization Report. Global Tuberculosis Control, Surveillance, Planning, Financing, W.H.O./HTM/TB/2005. Geneva: World Health Organization; 2005. Available from: http://library.cphs.chula.ac.th/ Ebooks/AnnualReport/TB/TB2005.pdf. Accessed March 04, 2016.

14. World Health Organization. Antimicrobial resistance. Fact Sheet No. 194. Updated 2015. Available from: http://www.who.int/ mediacentre/factsheets/fs194/en/. Accessed November 10, 2015.

15. Bisht R, Katiyar A, Singh R, Mittal P. Antibiotic resistance - a global issue of concern. Asian J Pharm Clin Res. 2009;2(2):1043-1049.

16. Roger FG, Greenwood D, Norbby SR, Whitley RJ. Antibiotic and Chemotherapy, The Problem of Resistance. 8th ed. Edinburgh: Churchill Livingstone; 2003:25-47.

17. Magiorakos AP, Srinivasan A, Carey RB, et al. Multidrug-resistant, extensively drug-resistant and pandrug-resistant bacteria: an international expert proposal for interim standard definitions for acquired resistance. Clin Microbiol Infect. 2012;18(3):268-281.

18. Levy SB. Factors impacting on the problem of antibiotic resistance. J Antimicrob Chemother. 2002;49(1):25-30.

19. Tripathi KD. Essentials of Medical Pharmacology, Antimicrobial Drugs: General Consideration. 5th ed. New Delhi: Jaypee Brother's Medical Publishers (P) Ltd; 2003:627-640.

20. Cole EC, Addison RM, Rubino JR, et al. Investigation of antibiotic and antibacterial agent cross-resistance in target bacteria from homes of antibacterial product users and nonusers. J Appl Microbiol. 2003;95(4):664-676.

21. Barker KF. Antibiotic resistance: a current perspective. Br J Clin Pharmacol. 1999;48(2):109-124.

22. Houang ET, Greenwood D. Aminoglycoside cross-resistance patterns of gentamicin-resistant bacteria. J Clin Pathol. 1977;30(8):738-744.

23. Cars O, Mölstad S, Melander A. Variation in antibiotic use in the European Union. Lancet. 2001;357(9271):1851-1853.

24. Llor C, Bjerrum L. Antimicrobial resistance: risk associated with antibiotic overuse and initiatives to reduce the problem. Ther Adv Drug Saf. 2014;5(6):229-241.

25. Levy SB. The challenge of antibiotic resistance. Sci Am. 1998;278(3): 46-53.
26. Wise $\mathrm{R}$, Hart $\mathrm{T}, \mathrm{Cars} \mathrm{O}$, et al. Antimicrobial resistance. Is a major threat to public health. BMJ. 1998;317(7159):609-610.

27. Richards J. Emergence \& spread of multiresistant organisms: can infection control measures help? Int J Infect Control. 2009; v5:i2.

28. Harrison PF, Lederberg J, editors. Antimicrobial Resistance: Issues and Options. Washington, DC: National Academy Press; 1998.

29. Levy SB. The Antibiotic Paradox. How Miracle Drugs Are Destroying the Miracle. New York: Plenum Publishing; 2002.

30. Levy SB. Antibiotic resistance: an ecological imbalance. In: Chadwick D, Goode J, editors. Antibiotic Resistance: Origins, Evolution, Selection and Spread. Chichester: Wiley (Ciba Foundation Symposium 207); 1997:1-14.

31. Cars O, Hedin A, Heddini A. The global need for effective antibiotics moving towards concerted action. Drug Resist Updat. 2011;14:68-69.

32. Lenski RE. Bacterial evolution and the cost of antibiotic resistance. Int Microbiol. 1998;1(4):265-270.

33. van der Bij AK, Pitout JD. The role of international travel in the worldwide spread of multiresistant Enterobacteriaceae. $J$ Antimicrob Chemother. 2012;67(9):2090-2100.

34. Johnson AP, Woodford N. Global spread of antibiotic resistance: the example of New Delhi metallo- $\beta$-lactamase (NDM)-mediated carbapenem resistance. J Med Microbiol. 2013;62:499-513.

35. Brandt C, Makarewicz O, Fischer T, et al. The bigger picture: the history of antibiotics and antimicrobial resistance displayed by scientometric data. Int J Antimicrob Agents. 2014;44(5):424-430.

36. United States Centers for Disease Control and Prevention. Antibiotic Resistance Threats in the United States; 2013. Available from: http:// www.cdc.gov/drugresistance/pdf/ar-threats-2013-508.pdf. Accessed November 10, 2015.

37. World Health Organization. Antimicrobial Resistance Global Report on Surveillance 2014. Geneva: World Health Organization. Available from: http://apps.who.int/iris/bitstream/10665/112642/1/9789241564 748_eng.pdf. Accessed November 10, 2015.

38. Hasan R, Jabeen K, Mehraj V, et al. Trends in Mycobacterium tuberculosis resistance, Pakistan, 1990-2007. Int J Infect Dis. 2009;13(6): e377-e382.

39. Carlet J, Jarlier V, Harbarth S, Voss A, Goossens H, Pittet D; Participants of the 3rd World Healthcare-Associated Infections Forum. Ready for a world without antibiotics? The Pensières Antibiotic Resistance Call to Action. Antimicrob Resist Infect Control. 2012;1(1):11.

40. Lim VK, Cheong YM, Suleiman AB. Pattern of antibiotic usage in hospitals in Malaysia. Singapore Med J. 1993;34(6):525-528.

41. Cheong YM, Lim VK, Jegathesan M, Suleiman AB. Antimicrobial resistance in 6 Malaysian general hospitals. Med J Malaysia. 1994;49(4): 317-326.

42. Norazah A, Lim VKE, Munirah SN, Kamel AGM. Staphylococcus aureus carriage in selected communities and their antibiotic susceptibility patterns. Med J Malaysia. 2003;58:255-261.

43. Lee WS, Puthucheary SD. Species distribution and antibiotic resistance of Shigella isolates in an urban community in Malaysia. Med J Malaysia. 2003;58:262-267.

44. Teng CL, Nurjahan MI, Hashim NA, Punithambigai P, Leong KC, Mihat $\mathrm{Ob}$. Upper respiratory tract infections: To what extent is the management evidence based? Med J Malaysia. 2003;58:159-166.

45. Lim VKE. Antibiotic resistance in the community. Med J Malaysia. 2003;58(2):156-158.

46. Teng CL, Leong KC, Aljunid SM, Cheah M. Antibiotic prescription in upper respiratory tract infections. Asia Pac Fam Med. 2004;3(1-2):38-45.

47. Teng CL, Tong SF, Khoo EM, et al. Antibiotics for URTI and UTI prescribing in Malaysian primary care settings. Aust Fam Physician. 2011;40(5):325-329.

48. Kho BP, Ong CM, Tan FT, Wee CY. Antibiotic prescribing for upper respiratory tract infections in Sarawak district hospitals. Med J Malaysia. 2013;68(2):136-140.

49. Chan GC, Tang SF. Parental knowledge, attitudes and antibiotic use for acute upper respiratory tract infection in children attending a primary healthcare clinic in Malaysia. Singapore Med J. 2006;47(4):266-270. 
50. Ling Oh A, Hassali MA, Al-Haddad MS, Syed Sulaiman SA, Shafie AA, Awaisu A. Public knowledge and attitudes towards antibiotic usage: a cross-sectional study among the general public in the state of Penang, Malaysia. J Infect Dev Ctries. 2011;5(5):338-347.

51. Lim KK, Teh CC. A cross-sectional study of public knowledge and attitude towards antibiotics in Putrajaya, Malaysia. South Med Rev. 2012;5(2):26-33.

52. Islahudin F, Tamezi AMA, Shah NM. Knowledge, attitudes, and practices about antibiotic use among the general public in Malaysia. Southeast Asian J Trop Med Public Health. 2014:45(6): 1474-1482.

53. Lim V. Antibiotic Stewardship. IeJSME. 2012:6(Suppl 1):S75-S79.

54. World Health Organization. The Evolving Threat of Antimicrobial Resistance: Options for Action. Geneva: World Health Organization; 2012. Available from: http://apps.who.int/iris/bitstream/10665/44812/ 1/9789241503181_eng.pdf. Accessed November 10, 2015.

55. Wright EP, Jain P. Survey of antibiotic knowledge amongst final year medical students. J Antimicrob Chemother. 2004;53:550-551

56. Humphreys H, Dillane T, O'Connell B, Luke LC. Survey of recent medical graduates' knowledge and understanding of the treatment and prevention of infection. Ir Med J. 2006;99:58-59.

57. Abbo LM, Cosgrove SE, Pottinger PS, et al. Medical students' perceptions and knowledge about antimicrobial stewardship: how are we educating our future prescribers? Clin Infect Dis. 2013;57:631-638.

58. Kamulegeya A, Kizito AN, Balidawa H. Ugandan medical and health sciences interns' infection control knowledge and practices. $J$ Infect Dev Ctries. 2013;7(10):726-733.

59. Jorak A, Keihanian F, Saeidinia A, Heidarzadeh A, Saeidinia F. A crosssectional study on knowledge, attitude, and practice of medical students toward antibiotic resistance and its prescription, Iran. Adv Environ Biol. 2014;8(17):675-681.

60. Harakeh S, Almatrafi M, Ungapen H, et al. Perceptions of medical students towards antibiotic prescribing for upper respiratory tract infections in Saudi Arabia. BMJ Open Respir Res. 2015;2:e00078.

61. Suaifan GARY, Shehadeh M, Darwish DA, Al-Ijel H, Yousef Al-M M, Darwish RM. A cross-sectional study on knowledge, attitude and behavior related to antibiotic use and resistance among medical and non-medical university students in Jordan. Afr J Phar Pharmacol. 2012; 6(10):763-770.

62. Thriemer K, Katuala Y, Batoko B, et al. Antibiotic prescribing in DR Congo: A knowledge, attitude, and practice survey among medical doctors and students. PLoS One. 2013;8(2):e55495.

63. Huang Y, Gu J, Zhang M, et al. Knowledge, attitude and practice of antibiotics: a questionnaire study among 2500 Chinese students. $B M C$ Med Educ. 2013;13:163.

64. Kållberg C. Medical Students' Views on the Current and Future Antibiotic Resistance Situation. Sahlgrenska Academy, University of Gothenburg. Available: http://www.reactgroup.org/uploads/react/ resources/260/Medical $\% 20$ students $\%$ E2\%80\%99\%20views $\% 20$ on $\% 20$ the $\% 20$ current $\% 20$ and $\% 20$ future $\% 20$ antibiotic $\% 20$ resistance $\% 20$ situation.en.319.pdf. Accessed November 10, 2015.

65. Dyar OJ, Pulcini C, Howard P, Nathwani D; ESGAP (ESCMID Study Group for Antibiotic Policies). European medical students: a first multicentre study of knowledge, attitudes, and perceptions of antibiotic prescribing and antibiotic resistance. $J$ Antimicrob Chemother. 2014;69(3):842-846.

66. Laxminarayan R, Duse A, Wattal C, et al. Antibiotic resistance - the need for global solutions. Lancet Infect Dis. 2013;13(12):1057-1098

67. World Health Organization. Managing for rational medicine use. Essential Medicines and Health Products Information Portal. Geneva: World Health Organization; 2012, Chapter 27. Available from: http://apps. who.int/medicinedocs/documents/s19604en/s19604en.pdf. Accessed November 10, 2015.

68. World Health Organization. Promoting Rational Use of Medicines: Core Components. Geneva: World Health Organization; 2002. Available from: http://www.who.int/medicines/publications/policyperspectives/ ppm05en.pdf. Accessed November 10, 2015.
69. Orme M, Frolich J, Vrhovac B; Education Sub-Committee of the European Association for Clinical Pharmacology and Therapeutics. Towards a core curriculum in clinical pharmacology for undergraduate medical students in Europe. Eur J Clin Pharmacol. 2002;58:635-640.

70. Jamshed SQ, Elkalmi R, Rajiah K, et al. Understanding of antibiotic use and resistance among final-year pharmacy and medical students: a pilot study. J Infect Dev Ctries. 2014;8(6):780-785.

71. Rahman NI, Aziz AA, Zulkifli Z, et al. Perceptions of students in different phases of medical education of the educational environment: Universiti Sultan Zainal Abidin. Adv Med Educ Pract. 2015;6:211-222.

72. Ismail S, Salam A, Alattraqchi AG, et al. Evaluation of doctors' performance as facilitators in basic medical science lecture classes in a new Malaysian medical school. Adv Med Educ Pract. 2015;6:231-237.

73. Malaysian Qualifications Agency. Code of Practice for Program Accreditation. 2nd ed. Selangor Darul Ehsan, Malaysia, 2008.

74. Malaysian Qualifications Agency. Code of Practice for Institutional Audit. 1st ed. Selangor Darul Ehsan, Malaysia, 2008.

75. Salam A, Yousuf R, Islam MZ, et al. Professionalism of future medical professionals in Universiti Sultan Zainal Abidin, Malaysia. Bangladesh J Pharmacol. 2013;8:124-130.

76. Salam A, Haque M, Islam MZ, et al. Comparative study of professionalism of future medical professionals among three private medical colleges of Bangladesh. Asian J Pharm Clin Res. 2013;6(3):170-179.

77. Salam A, Haque M, Helali AM, et al. Comparative study on professionalism of forthcoming medical doctors between two private medical colleges in Savar, Bangladesh. Int J Pharm Pharm Sci. 2013;59 (Suppl 3):659-665.

78. Islam MZ, Salam A, Helali AM, et al. Comparative study of professionalism of future medical doctors between Malaysia and Bangladesh. J App Pharm Sci. 2014;4(4):66-71.

79. ECDC/EMEA Joint Technical Report. The Bacterial Challenge: Time to React; 2009. Available from: http://ecdc.europa.eu/en/publications/ Publications/0909_TER_The_Bacterial_Challenge_Time_to_ React.pdf. Accessed November 10, 2015.

80. World Health Organization. WHO methods and data sources for global burden of disease estimates 2000-2011. Global Health Estimates Technical Paper WHO/HIS/HSI/GHE/2013.4. WHO, Geneva; 2013. Accessed November 10, 2015.

81. Kongsved SM, Basnov M, Holm-Christensen K, Hjollund NH. Response rate and completeness of questionnaires: a randomized study of Internet versus paper-and-pencil versions. J Med Internet Res. 2007; 9(3):e25.

82. Chen MK, Chevalier JA. Are women overinvesting in education? Evidence from the medical profession. J Hum Cap. 2012;6(2):124-149.

83. BBC. Women docs "weakening" medicine. 2004. Available from: http:// news.bbc.co.uk/1/hi/health/3527184.stm. Accessed November 10, 2015.

84. Elston MA. Women and medicine: the future. Royal College of Physicians; 2009. Available from: https://www.rcplondon.ac.uk/sites/ default/files/documents/women-and-medicine-future-full-report.pdf. Accessed November 10, 2015.

85. Pulcini C, Williams F, Molinari N, Davey P, Nathwani D. Junior doctors' knowledge and perceptions of antibiotic resistance and prescribing: a survey in France and Scotland. Clin Microbiol Infect. 2011;17(1):80-87.

86. Aggarwal S, Mathew J, Singh H, Sharma V. Attitude, and perception of junior resident doctors' regarding antibiotic resistance - a pilot study. J Acute Dis. 2014;3(1):6-9.

87. Hoque R, Mostafa A, Haque M. Intern doctors' views on the current and future antibiotic resistance situation of Chattagram Maa O Shishu Hospital Medical College, Bangladesh. Ther Clin Risk Manag. 2015; 11:1177-1185.

88. Abera B, Kibret M, Mulu W. Knowledge and beliefs on antimicrobial resistance among physicians and nurses in hospitals in Amhara Region, Ethiopia. BMC Pharmacol Toxicol. 2014;15(1):26.

89. Sutradhar KB, Saha A, Huda NH, Uddin R. Irrational use of antibiotics and antibiotic resistance in Southern Rural Bangladesh: perspectives from both the physicians and patients. Annu Res Rev Biol. 2014;4(9): $1421-1430$. 
90. Navarro-San Francisco C, Del Toro MD, Cobo J, et al. Knowledge and perceptions of junior and senior Spanish resident doctors about antibiotic use and resistance: results of a multicenter survey. Enferm Infecc Microbiol Clin. 2013;31(4):199-204.

91. SARI Infection Control Subcommittee. Guidelines for Hand Hygiene in Irish Health Care Settings. Published on behalf of SARI by HSE, Health Protection Surveillance Centre. SARI Infection Control Subcommittee; 2004:1-51. Available from: https://www.hpsc.ie/A-Z/Gastroenteric/ Handwashing/Publications/File,1047,en.pdf. Accessed November 10, 2015.
92. Centers for Disease Control and Prevention. Guideline for hand hygiene in health-care settings: recommendations of the Healthcare Infection Control Practices Advisory Committee and the HICPAC/SHEA/APIC/ IDSA Hand Hygiene Task Force. MMWR Recomm Rep. 2002;51:1-45, quiz CE1-E4. Available: http://www.cdc.gov/mmwr/PDF/rr/rr5116 pdf. Accessed March 04, 2016.

93. Sierles FS, Brodkey AC, Cleary LM, et al. Medical students' exposure to and attitudes about drug company interactions: a national survey. JAMA. 2005;294(9):1034-1042.

\section{Publish your work in this journal}

Therapeutics and Clinical Risk Management is an international, peerreviewed journal of clinical therapeutics and risk management, focusing on concise rapid reporting of clinical studies in all therapeutic areas, outcomes, safety, and programs for the effective, safe, and sustained use of medicines. This journal is indexed on PubMed Central, CAS,
EMBase, Scopus and the Elsevier Bibliographic databases. The manuscript management system is completely online and includes a very quick and fair peer-review system, which is all easy to use. Visit http://www.dovepress.com/testimonials.php to read real quotes from published authors.

Submit your manuscript here: http://www.dovepress.com/therapeutics-and-clinical-risk-management-journal 